THE TILTED PLAYING FIELD 
This page intentionally left blank 


\title{
THE TILTED PLAYING FIELD
}

Is Criminal Justice Unfair?

\author{
H. Richard Uviller
}


Published with assistance from the

Kingsley Trust Association Publication Fund

established by the Scroll and Key Society of Yale College.

Copyright $(1999$ by Yale University. All rights reserved. This book may not be reproduced, in whole or in part, including illustrations, in any form (beyond that copying permitted by Sections 107 and 108 of the U.S. Copyright Law and except by reviewers for the public press), without written permission from the publishers.

Designed by Rebecca Gibb. Set in Adobe Garamond and Univers types by Keystone Typesetting, Inc., Orwigsburg, Pennsylvania. Printed in the United States of America.

Library of Congress Cataloging-in-Publication Data

Uviller, H. Richard.

The tilted playing field : is criminal justice unfair? I

H. Richard Uviller.

p. $\quad \mathrm{cm}$.

Includes index.

ISBN 0-300-07584-7 (cloth : alk. paper)

I. Discrimination in criminal justice administration-United

States. 2. Criminal justice, Administration of-Moral and ethical aspects-United States. I. Title.

HV9950.U85 1999

$364^{\prime} .089^{\prime} 00973-\mathrm{dc21}$

98-46459

A catalogue record for this book is available from the British Library.

The paper in this book meets the guidelines for permanence and durability of the Committee on Production Guidelines for Book Longevity of the Council on Library Resources. 
To my esteemed colleagues on the Columbia University law faculty, and especially to my close friends among them. For almost thirty years I have felt privileged to be in this company. They have taught me to appreciate the rare beauty of a good idea, well expressed. 
This page intentionally left blank 